\title{
WIRELESS SMART HOME SYSTEM MENGGUNAKAN INTERNET OF THINGS
}

\author{
Budi Artono, Fredy Susanto \\ Teknik Komputer Kontrol, Politeknik Negeri Madiun \\ Email: budiartono@pnm.ac.id, fredy@pnm.ac.id
}

\begin{abstract}
Aktivitas di dalam rumah merupakan rutinitas yang menuntut alokasi waktu yang cukup lama, banyak aktivitas yang dilakukan diruangan ini. Perkembangan teknologi memberi banyak perubahan dalam kehidupan. Perubahannya salalu memberi nilai menjadi lebih baik, seperti diantaranya adalah memberikan kemudahan dalam mengerjakan pekerjaan. Salah satu perkembangan teknologi adalah sistem rumah pintar (smart home system) yang bisa diterapkan di kehidupan sehari-hari. Sistem rumah pintar (smart home system) adalah alat yang mampu dan bisa bekerja secara otomatis berdasarkan inputan dimana kali ini inputan diproses melalui web dan secara program tertanam juga dalam Arduino. Wifi sebagai media komunikasi untuk mengirimkan data atau masukan dari aplikasi web berfungsi sebagai alat untuk mengendalikan peralatan rumah dari jarak jauh. Secara umum, kontrol peralatan rumah saat ini masih bekerja secara manual sehingga kurang efektif, tujuan perancangan sistem rumah pintar ini adalah untuk membuat alat yang bisa membantu orang untuk melakukan aktivitas di rumah yaitu mengendalikan peralatan rumah menggunakan smartphone secara otomatis melalui aplikasi web pada O.S android dengan menerapkan Internet of Things. Internet of Things (IoT) telah berkembang dengan cepat seiring berkembangnya perangkat smartphone dan sensor cerdas. Istilah IoT mengacu pada konektivitas jaringan dengan kemampuan cerdas, bertukar dan mengkonsumsi data dengan campur tangan manusia yang sangat sedikit. Dalam tulisan ini, kami memperkenalkan desain sistem smart home IoT berdasarkan aplikasi web serta pada aplikasi handphone O.S android dengan menerapkan sistem prototipe berbasis Arduino.
\end{abstract}

Kata kunci-Wifi, smart home system, Internet of Things, Arduino.

\section{Pendahuluan}

Lampu merupakan sumber cahaya yang sangat penting sebagai pengganti matahari. Penggunaan lampu dimasyarakat sekarang ini dinilai kurang efektif dan masih sering mengabaikan penggunaannya, sering kali lampu masih tetap menyala walaupun tidak dipakai. Hal semacam ini merupakan suatu pemborosan disisi lain proses mematikan dan menghidupkan lampu secara manual masih dirasa banyak membuang banyak waktu, Oleh karena itu perlu dibuat suatu sistem kontrol lampu serta system yang mampu untuk memoitor agar penggunaannya menjadi menjadi lebih efektif efesien.

Internet sebagai bagian dari perkembangan teknologi yang sangat berkembang pesat dikehidupan masyarakat saat ini telah mampu untuk digunakan sebagai media komunikasi dan kontrol terhadap perangkat dari jarak jauh selama masih terkoneksi dan saling terhubung. Internet of Things (IoT) merupakan sebuah pengembangan komunikasi jaringan dari benda yang saling terkait, terhubung satu dengan yang lain lewat komunikasi internet serta dapat saling bertukar data yang kemudian mengubahnya menjadi informasi.

Cayenne adalah platform IoT (Internet of Things) yang sekaligus berfungsi sebagai server yang mampu menyimpan project yang sedang dibuat. Cayenne mendukung dan sangat support terhadap berbagai jenis mikrokontroler. Pada cayenne selain berbagai kelebihannya tersebut, masih ada fitur yang membuat Cayenne lebih user-friendly yaitu adanya aplikasi berbasis smartphone dengan OS Android, IOS, maupun Windows Phone sehingga memudahkan dalam membuat berbagai jenis perangkat elektronik dengan kendali jarak jauh melalui internet.

Penelitian terdahulu tentang "LED control system with cayenne framework for the Internet of Things (IoT)" telah dibuat dan menghasilkan sistem kontrol LED dengan memanfaatkan cayenne meenggunakan media wifi sebagai kontrol jarak jauh [1]. Selanjutnya penelitian tentang sistem kendali otomatis pada Smart Home menggunakan modul Arduino" didapatkan hasil bahwa bekerja secara otomatis ketika seseorang masuk ke dalam rumah. Lampu ruang akan menyala, kipas angin akan bekerja sesuai dengan kondisi suhu ruang dan perangkat pengusir nyamuk akan bekerja secara otomatis [2]. 
Penelitian yang lain dengan judul "Aplikasi Rumah Pintar (Smart Home) Pengendali Peralatan Elektronik Rumah Tangga Berbasis Web" telah berhasil membuat perancangan smart home dengan menggunakan Raspberry Pi berbasis web, Saklar lampu dikontrol dengan menggunakan interface web yang sudah terhubung ke GPIO. Raspberry Pi digunakan sebagai server yang menghubungkan antara hardware dan software yang dapat dipakai oleh user secara langsung [3]. Penelitian yang berikutnya adalah membuat ContextAware Smart Home dengan menggunakan Internet Of Things yang didapatkan hasil bahwa monitoring kondisi lingkungan rumah sudah dapat diakses secara mudah oleh user serta mampu mengontrol perangkat rumah secara langsung seperti lampu dan pintu dengan menambah konsep IoT [4].

\section{A. Smart Home}

\section{Metodologi}

Smart Home merupakan salah satu cabang dari ubiquitos and pervasive computing. Smart Home erat kaitannya dengan kecerdasan buatan yang digunakan untuk meningkatkan faktor kenyamanan, keamanaan dan penghematan energi dalam suatu rumah. Smart Home menawarkan kualitas hidup yang lebih mudah dengan mengenalkan otomatisasi peralatan rumah tangga dan asistan rumah tangga. Smart home merupakan salah satu penerapan dari cabang ilmu pervasive computing. Beberapa istilah yang merujuk ke smart home antara lain adalah home automation, smart home, domotique, intelligent home, adaptive home dan aware home.

Definisi terbaru yang telah disepakati bersama dan banyak dipublikasikan smart home adalah merupakan sebuah perpaduan dari jaringan komunikasi yang terhubung ke perangkat rumah dan memungkinan untuk dikontrol, dimonitoring dan diakses secara jarak jauh. Pada penelitian Wireless Smart Home System menggunakan Internet Of Things kali ini fokus pada 2 fungsi smart home yaitu sebagai remote accces dan home automation dan dengan tujuan untuk menggabungkan 2 fungsi smart home tersebut.

\section{B. Internet of Things (IoT)}

Internet of things adalah sebuah teknologi yang memungkinkan kita untuk menghubungkan mesin, peralatan, dan benda fisik lainnya dengan sensor jaringan dan aktuator untuk memperoleh data dan memproses serta mampu mengelola kinerjanya sendiri, sehingga dimungkinkan adanya mesin untuk saling berkolaborasi. Sebuah publikasi mengenai Internet of things menjelaskan bahwa internet of things adalah suatu keadaan ketika benda memiliki sebuah identitas, bisa beroperasi secara intelijen, dan bisa berkomunikasi dengan sosial, lingkungan, serta pada setiap penggunanya. Tujuan Internet of things adalah untuk membuat manusia berinteraksi dengan benda lebih mudah, bahkan dengan tujuan supaya benda juga bisa saling berkomunikasi antar satu benda dengan benda yang lainnya.

Dalam sebuah artikel yang ditullis oleh Michael Hendrix, McKinsey Global Institute, dijelaskan bahwa internet of things menjadi salah satu teknologi yang akan gencar di masa depan. Internet of things akan membawa pengaruh perkembangan dari sisi ekonomi dengan memberikan peluang yang sangat besar bahkan sampai 6.2 triliun Dolar Amerika Serikat. Pengaruh ekonomi ini dilihat dari industri internet of things yang akan menempati posisi ke tiga terbesar setelah mobile internet dan automation of knowledge work. Hal ini terbukti bahwa teknologi internet of things akan benar-benar berkembang dan menjadikan sebuah tren tesendiri di dunia nantinya.

Saat ini kita sudah melihat bagaimana sensor-sensor berkembang dan memengaruhi perkembangan dan kemajuan teknologi di dunia. Tentu akan banyak perusahaan yang menggunakan internet of things, dan berusaha untuk mengembangkan. Internet of things saat ini masih bisa dikatakan sesuatu yang sangat baru dan masih bisa terus untuk dikembangkan.

Salah satu contoh perkembangan internet of things yang sudah dan masih dimungkinkan untuk dapat dikembangkan lagi adalah Internet of things yang difungsikan sebagai pemantauan jarak jauh, sistem ini merupakan salah satu bentuk sistem aplikasi yang paling sering ditemukan. Salah satu caranya adalah dengan menambahkan sensor pada suatu objek benda yang ingin dipantau atau dimonitoring untuk mengetahui keberadaanya atau bahkan kondisi juga tata letaknya, Sensor tersebut dikoneksikan dengan internet dengan menambahkan sebuah pemetaan atau mapping sehingga bisa diketahui letak posisinya. Sehigga diperoleh data apa saja yang dibutuhkan dari sensor dan dapat difungsikan untuk memantaunya dari jarak jauh dengan jaringan internet, bahkan dapat langsung dipantau dengan menggunakan handphone yang sudah mendukung untuk koneksi internet.

Contoh diantaranya yang lain adalah dalam dunia 
kesehatan dengan menambahkan sensor yang dapat mendeteksi temperatur, suhu, kelembaban, atau bahkan tekanan udara yang dipasangkan atau ditambahkan pada alat yang dipakai dan kontak langsung dengan pasien sehingga dapat memudahkan seorang dokter dalam memantau dan memonitor kondisi pasien. Dengan adanya internet of things seorang dokter dapat lebih mudah dalam memantau, memeriksa dan menangani pasiennya setiap hari. Inovasi-inovasi ini sangat membantu dan apabila mampu dikembangkan serta diterapkan mampu menghasilkan penghematan biaya yang sangat besar.

Mudah mengatakan bahwa smartphone saat ini adalah merupakan perangkat IoT. Smartphone sudah memiliki kemampuan untuk terkoneksi dengan internet, dan sudah dilengkapi dengan beberapa sensor seperti layar sentuh, sensor cahaya, akselerometer, gyroskop, dan kompas. Akan tetapi satu hal yang terpenting dalam IoT, bahwa bagaimana sensor-sensor ini dapat mendeteksi dan berkomunikasi dengan perangkat lain, dan ini yang tidak ditemukan pada smartphone terkecuali jika kita memasang aplikasi yang membuatnya melakukan hal tersebut.

Dengan perkembangan teknologi dapat memudahkan segala bentuk aktifitas kehidupan manusia. Semua sebenarnya bermula pada saat awal tahun 90 -an orang mulai mengenal teknologi Internet of Things. Mark Weiser seorang staf Xerox Palo Alto Research Center pada tahun 1991 menerbitkan paper tentang ubiquitous computing dengan judul "The Computer of the 21st Century" dimana dalam papernya dijelaskan tentang visi kontemporer yang berkaitan langsung dengan perkembangan teknologi internet of thing saat ini [5].

Internet of Things muncul dan diperkenalkan oleh Kevin Ashton, seorang entrepreneur yang konsen meneliti terhadap teknologi asal UK. Istilah Internet of Things pertama kali dipakai sebagai judul presentasi dalam seminar di depan perusahaan penyedia produk harian dari Amerika, Procter \& Gamble (P\&G). Kevin menjelaskan bahwa IoT sebagai sistem dimana bendabenda fisik dapat saling terhubung ke internet melalui sensor yang ada di mana-mana [6].

Internet of things pada dasarnya adalah memulai sistem dengan cara membuat suatu koneksi atau sebuah komunikasi antara mesin dengan mesin, sehingga mesin mesin tersebut dapat berinteraksi dan dapat bekerja secara independen sesuai dengan data yang diperoleh, yang kemudian dapat mengolahnya secara mandiri. Sistem IoT dapat tumbuh menjadi lebih kompleks dengan sejumlah besar perangkat yang dapat saling berhubungan untuk menghasilkan layanan yang mendukung untuk proses yang lebih kompleks. Seperti yang digambarkan pada Gambar 1 berikut.

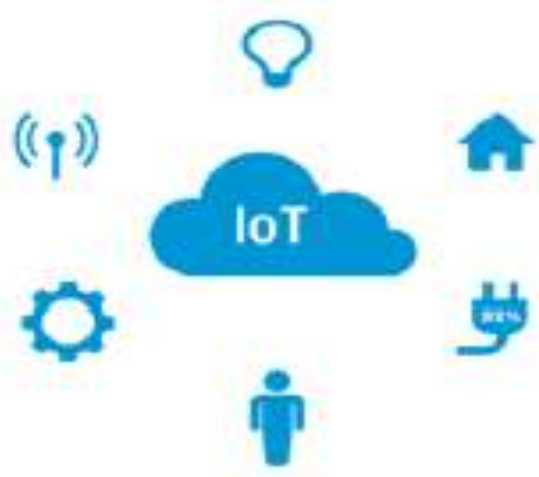

Gambar 1. Representasi IoT [7]

"Internet of Things dapat digambarkan sebagai sebuah jaringan yang mampu untuk melakukan konfigurasi sendiri, serta adaptif, sehingga membentuk sebuah jaringan kompleks yang saling berhubungan dengan berbagai perangkat ke Internet melalui penggunaan protokol komunikasi standar"[8].

\section{Arduino}

Arduino merupakan sebuah modul elektronik open source berbasis mikrokontroller Atmel AVR Atmega328. Arduino dirancang untuk memudahkan dalam perancangan prototipe hardware elektronik. Modul ini memiliki 14 pin digital input/output, 6 analog input, dan 5 volt power input yang dapat disediakan melalui power supply eksternal maupun konektor USB yang telah disediakan. Selain itu terdapat sebuah tombol reset yang dapat digunakan untuk menjalankan program yang telah di-upload kedalam chip dari awal. masing-masing pin digital dapat berfungsi sebagai input atau output, tergantung kebutuhan pengguna yang dapat dipilih melalui coding program. Terdapat beberapa versi Arduino, Arduino Rev. 3 adalah versi yang dirilis pada tahun 2012. Arduino ini dapat diprogram menggunakan software Arduino Sketch dengan menggunakan bahasa pemrograman $\mathrm{C}$.

Di dalam Arduino tidak diperlukan lagi perangkat chip progammer karena didalamnya sudah ada bootloader yang difungsikan untuk menangani upload program dari komputer. Selain itu Arduino juga sudah memiliki sarana komunikasi USB, sehingga pengguna laptop dapat menggunakan port USB yang sudah memiliki modul siap 
pakai (Shield) serta bisa ditancapkan pada Board Arduino. Input dan Output berupa data digital dan data analog yang dapat langsung menghubungkan Arduino dengan komponen pada pin-pin yang sudah disediakan pada arduino.

\section{Modul Wifi ESP8266}

Modul wifi ESP8266 merupakan modul wifi yang berfungsi sebagai perangkat tambahan pada mikrokontroler seperti Arduino agar dapat terhubung langsung dengan wifi dan membuat koneksi TCP/IP. Modul ini memiliki tiga mode wifi yaitu Station, Access Point dan Both. Modul ini juga dilengkapi dengan prosesor, memori dan GPIO dimana jumlah pin bergantung dengan jenis ESP8266 yang kita gunakan. Modul ini bisa berdiri sendiri tanpa menggunakan mikrokontroler apapun karena sudah memiliki perlengkapan layaknya mikrokontroler.

Firmware default yang digunakan oleh perangkat ini menggunakan AT Command, selain itu ada beberapa Firmware SDK yang digunakan oleh perangkat ini berbasis open source yang diantaranya adalah sebagai berikut:

d) Node MCU dengan menggunakan basic programming lua.

e) MicroPython dengan menggunakan basic programming python.

f) AT Command dengan menggunakan perintah perintah AT command.

Untuk pemrogramannya sendiri kita bisa menggunakan ESPlorer untuk Firmware berbasis Node MCU dan menggunakan putty sebagai terminal control untuk $A T$ Command. Untuk pemrogramannya sendiri kita bisa menggunakan ESPlorer untuk Firmware berbasis Node $M C U$ dan menggunakan putty sebagai terminal control untuk AT Command.

\section{E. PIR Motion Sensor}

PIR motion sensor adalah sensor yang digunakan untuk mendeteksi radiasi gelombang inframerah yang dibangkitkan oleh manusia. Sensor PIR didesain dan dirancang hanya mendeteksi pancaran infra merah dengan panjang gelombang 8-14 mikrometer. Sensor ini hanya akan mendeteksi jika objek bergerak atau secara teknis saat perubahan pancaran infra merah (falling up atau falling down). Pada umumnya sensor ini digunakan untuk mendeteksi pergerakan manusia.

F.. Sensor Suhu LM35
Sensor suhu LM35 adalah komponen elektronika yang memiliki fungsi untuk mengubah besaran suhu menjadi besaran listrik dalam bentuk tegangan. LM35 memiliki keakuratan tinggi dan kemudahan perancangan jika dibandingkan dengan sensor suhu yang lain, LM35 juga mempunyai keluaran impedansi yang rendah dan linieritas yang tinggi sehingga dapat dengan mudah dihubungkan dengan rangkaian kendali khusus serta tidak memerlukan penyetelan lanjutan. Tegangan ideal yang keluar dari LM35 mempunyai perbandingan $100^{\circ} \mathrm{C}$ setara dengan 1 volt. Sensor ini mempunyai pemanasan diri (self heating) kurang dari $0,1^{\circ} \mathrm{C}$, dapat dioperasikan dengan menggunakan power supply tunggal dan dapat dihubungkan antar muka (interface) rangkaian control yang sangat mudah. IC LM 35 sebagai sensor suhu yang teliti dan terkemas dalam bentuk Integrated Circuit (IC), dimana output tegangan keluaran sangat linear terhadap perubahan suhu.

\section{G. Sensor Suara}

Sensor suara adalah sensor yang cara kerjanya merubah besaran suara menjadi besaran listrik. Sensor ini berfungsi mengubah gelombang sinus suara menjadi gelombang sinus energi listrik (Alternating Sinusioda Electric Current). Sensor suara berkerja berdasarkan besar atau kecilnya kekuatan gelombang suara yang mengenai membran sensor. Sinyal yang masuk akan di olah sehingga akan menghasilkan satu kondisi yaitu kondisi 1 atau 0. Pada dasarnya prinsip kerja pada alat ini hampir mirip dengan cara kerja sensor sentuh pada perangkat seperti telepon genggam, laptop, dan notebook.

\section{G. Perancangan sistem}

Perancanagan sistem ini dilakukan dengan perencanaan sistem, implementasi sistem dan ujicoba sistem. Untuk mempermudah dalam merancang dan membuat sistem wireless smart home system menggunakan internet of things ini, Dirancang desain maket penempatan sensor \& lampu sebagai berikut : 


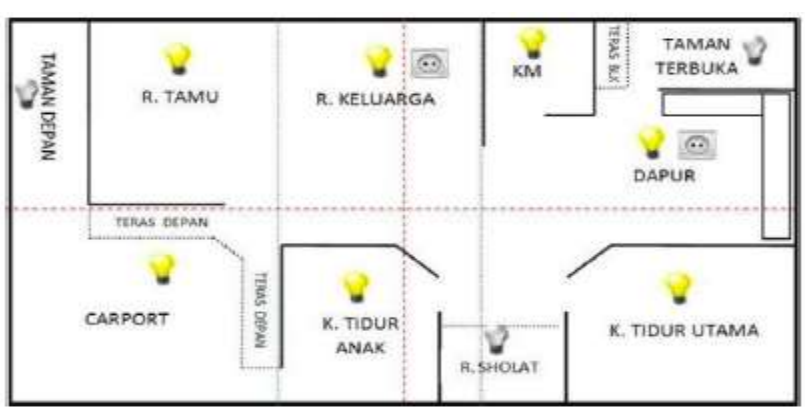

Gambar 2. Desain maket penempatan sensor \& lampu

Prinsip kerja dari wireless smart home system menggunakan internet of things ini adalah dengan memberikan inputan kepada masing - masing sensor yang berupa PIR motion sensor, sensor suhu LM35, dan sensor suara. Data yang telah diproses dan dihasilkan mikrokontroler akan diteruskan ke modul relay. Kemudian modul relay akan meneruskan data untuk menghidupkan atau mematikan lampu. Setiap lampu akan terkoneksi dengan internet, sehingga kondisi nyala lampu dapat terpantau dengan aplikasi cayenne. Melalui aplikasi cayenne, dapat dimonitor dan dilakukan kontrol baik secara manual dengan menekan tombol button atau secara otomatis dari fungsi masing-masing sensor yang telah terpasang. Sehingg dapat dilakukan kontrol serta monitoring terhadap lampu melalui jarak jauh selama arduino terkoneksi dengan internet.

\section{Hasil dan Analisa}

Pada bagian ini akan dijelaskan proses pembuatan peralatan dari wireless smart home system menggunakan internet of things yang dimulai dengan rancang bangun bentuk prototype sesuai Gambar 3 berikut:

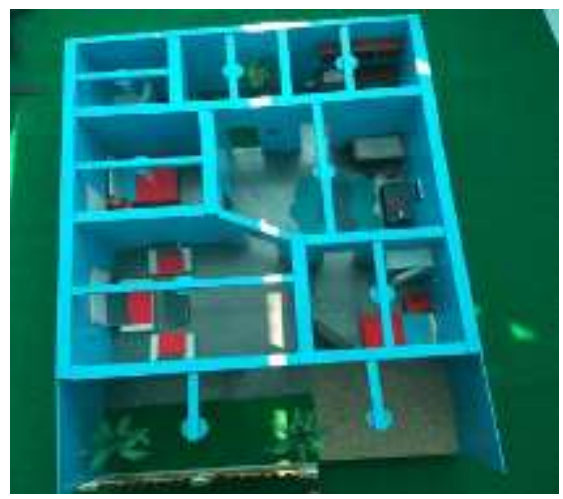

Gambar 3. Rancangan bentuk prototype smart home

Setelah hardware yang dirancang sudah siap kemudian dilanjutkan untuk membuat project di cayenne yang berfungsi sebagai monitoring dan kontrol lampu dengan media wifi dari jarak jauh.

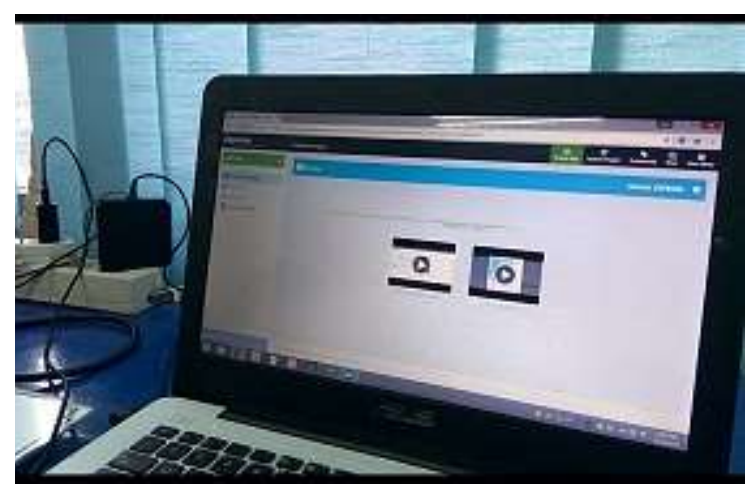

Gambar 4. Create proiect smart home pada web Cavenne.mvdevice.com

Pengujian pertama pada wireless smart home system menggunakan internet of things adalah dengan menggunakan sensor PIR, Pada pengujian ini proses pertama yang dilakukan adalah dengan tanpa memberi inputan yang berupa gerakan tangan sehingga sensor tidak memproses adanya data masuk dan hasil monitoring pada aplikasi cayenne menampilkan data bernilai 0 (Gambar 5), Kemudian proses pengujian ke berikutnya adalah dengan memberikan inputan berupa gerakan tangan yang akan dideteksi oleh sensor PIR sehingga memberikan inputan data bernilai 1 ke sensor dan relay akan bekerja menyalakan lampu disaat bersamaan kita bisa memonitor dari aplikasi cayenne yang akan menampilkan data hasil proses sensor pada tampilan dashboard berupa data bernilai 1 dan pada tampilan aplikasi juga akan ditampilkan tampilan virtual lampu dengan kondisi menyala (Gambar 6).

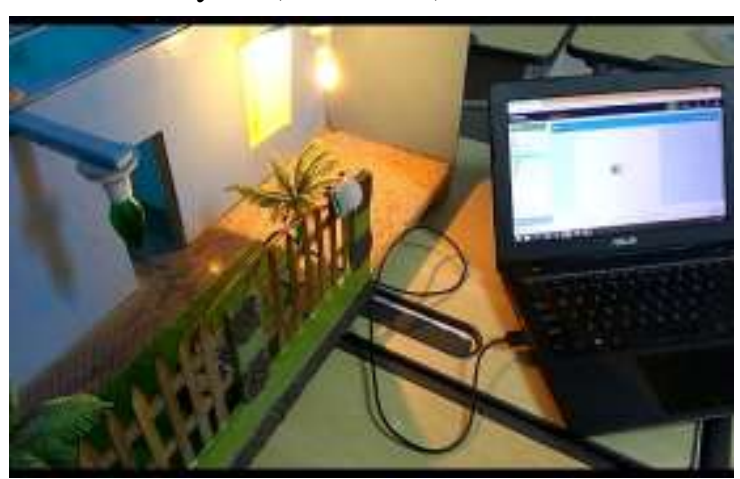

Gambar 5. Lampu mati dan hasil monitoring data bernilai 0 sensor PIR dengan cayenne 


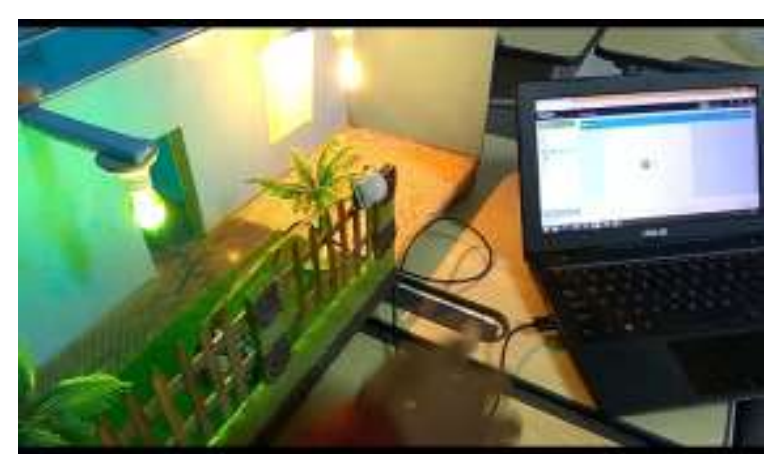

Gambar 6. Lampu nyala dan hasil monitoring data bernilai 1 sensor PIR dengan cayenne

Selanjutnya pengujian yang ke dua pada wireless smart home system menggunakan internet of things adalah dengan menggunakan sensor suara, Pada pengujian ini proses pertama yang dilakukan adalah dengan mengkodisikan tanpa memberi inputan berupa suara ke sensor sehingga sensor tidak memproses adanya data masuk dan hasil monitoring pada aplikasi cayenne dapat ditampilkan kondisi lampu mati dan pada dashboard cayenne tidak mendektesi adanya data yang masuk (Gambar 7), Kemudian proses pengujian berikutnya yang dilakukan adalah dengan memberi inputan berupa suara petikan jari yang akan langsung dideteksi oleh sensor suara sehingga relay akan bekerja menyalakan lampu di waktu bersamaan kita bisa memonitor pada tampilan dashboard cayenne yang menampilkan data hasil proses sensor suara sekaligus tampilan virtual lampu dengan kondisi menyala (Gambar 8) kondisi pengujian yang ke dua ini difungsikan sebuah tambahan trigger pada aplikasi cayenne untuk menentukan set point wireless smart home system.

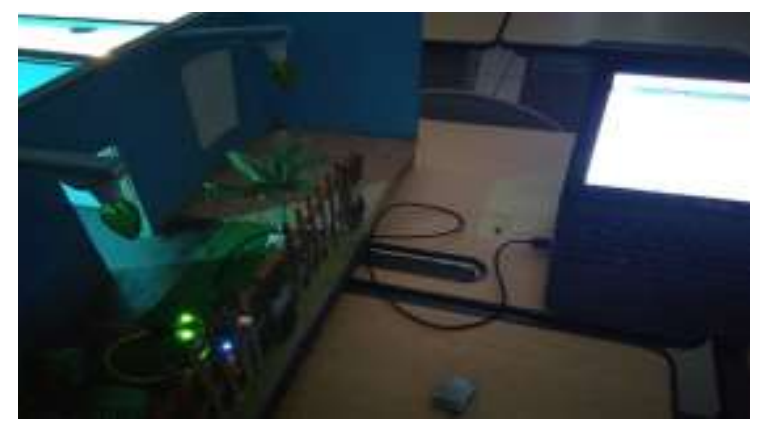

Gambar 7. Lampu mati dan hasil monitoring data dengan sensor suara

Pada pengujian yang ke tiga pada wireless smart home system menggunakan internet of things adalah dengan menggunakan sensor suhu LM35, Pada pengujian ini proses yang dilakukan adalah dengan mengkodisikan sensor suhu dengan inputan dibawah set poit yang telah ditentukan dengan trigger pada aplikasi cayenne sehingga sensor tidak memproses adanya data inputan dan hasil monitoring pada aplikasi cayenne dapat ditampilkan kondisi lampu mati serta pada dashboard cayenne tidak mendektesi adanya data yang diproses (Gambar 9), Kemudian proses pengujian berikutnya yang dilakukan adalah dengan memberi inputan berupa suhu di atas set point dengan menekan dengan jari sensor LM35 sehingga suhu sensor meningkat dari suhu awal karena panas tubuh, relay akan bekerja menyalakan lampu dan di waktu bersamaan bisa dimonitor pada tampilan dashboard cayenne yang menampilkan data hasil proses sensor suhu LM35 sekaligus tampilan virtual lampu dengan kondisi menyala (Gambar 10).

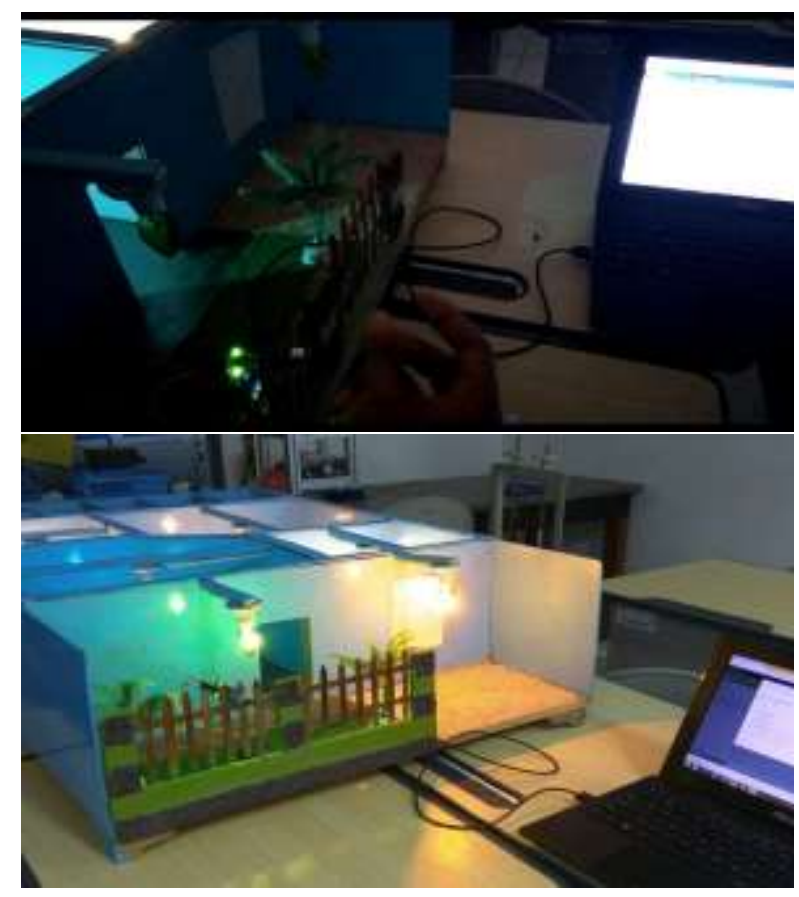

Gambar 8. Lampu nyala dan hasil monitoring data dengan sensor suara 


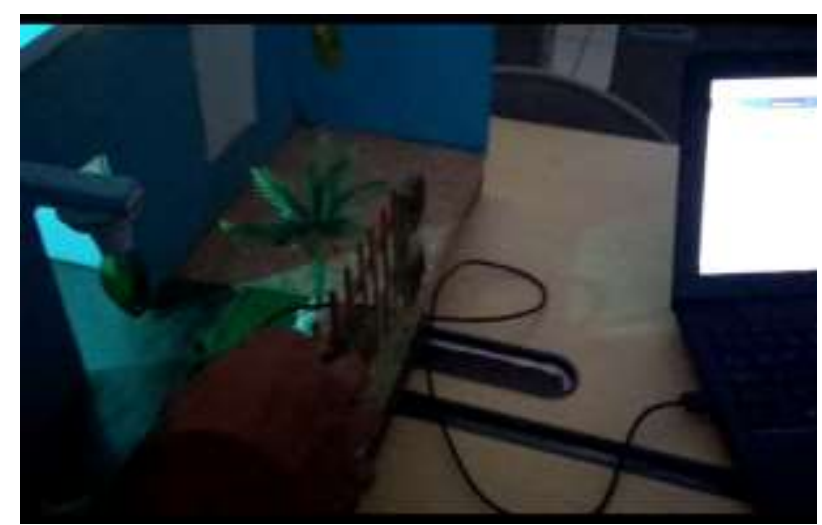

Gambar 9. Kondisi lampu mati dan data dari sensor suhu LM35 dengan cayenne

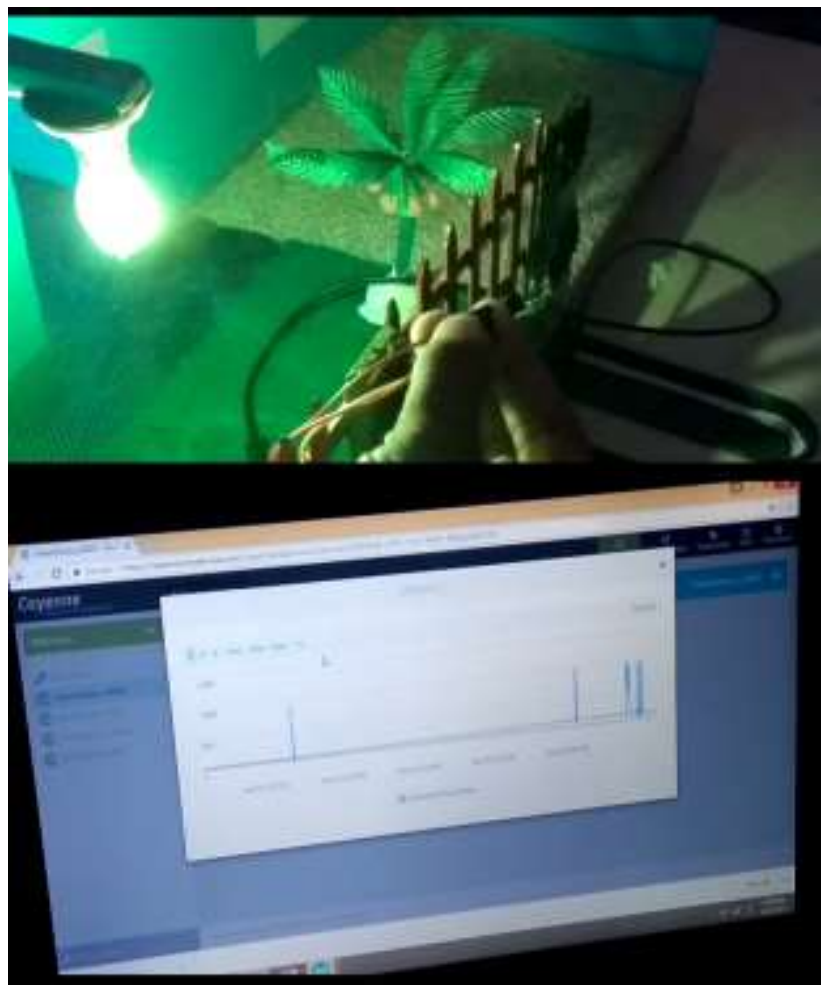

Gambar 10. Kondisi lampu nyala dan data di tampilan cayenne dengan sensor suhu LM35

\section{Kesimpulan}

Berdasarkan urian proses yang telah dilakukan maka diperoleh kesimpulan terhadap keseluruhan proses adalah sebagai berikut :

- wireless smart home system menggunakan internet of things telah dapat dilakukan dan dapat direalisasikan dengan menggunakan prototype serta dapat memonitor lampu pada prototype smart home sehingga dapat diketahui kondisi lampu dalam keadaan hidup atau mati.
- Sensor PIR, sensor suara dan sensor suhu LM 35 dapat bekerja dengan baik dan data dapat diproses oleh aplikasi cayenne ditunjukkan dengan tampilan pada dashbord yang menggabarkan nilai variabel dari sistem smart home dan tampilan grafik nilai sensor sesuai nilai data sensor.

\section{Daftar pustaka}

[17] Budi artono, "LED control system with cayenne framework for the Internet of Things" (IoT), JEECAE Vol.2, No.1, Mei 2017

18] Fauzan Masykur1, Fiqiana Prasetiyowati. maret 2016. "Aplikasi Rumah Pintar (Smart Home) Pengendali Peralatan Elektronik Rumah Tangga Berbasis Web", Vol. 3, No. 1, Maret 2016, hlm. 51-58

[19] Arif Setiawan, I Wayan Mustika, Teguh Bharata Adji. maret 2016. "PERANCANGAN CONTEXT-AWARE SMART HOME DENGAN MENGGUNAKAN INTERNET OF THINGS", Seminar Nasional Teknologi Informasi dan Komunikasi 2016 (SENTIKA 2016) ISSN: 2089-9815

[20] Nida Nabilah, dkk., "Pembuatan Prototipe Lampu Otomatis Untuk Penghematan Energi Berbasis Arduino di Departemen Fisika Fmipa IPB". Prosiding Seminar Nasional Fisika (E-Journal) SNF2016. VOLUME V, OKTOBER 2016 p-ISSN: 2339-0654 e-ISSN: 2476-9398 DOI: doi.org/10.21009/0305020115 http://snf-unj.ac.id/kumpulanprosiding/snf2016/.

[21] Suleman \& Anwar Taufik. 2016. "Prototype Rancangan Alat Pengendali Lampu Gedung Berbasis Android Dengan Mikrokontroller At89c2051". Indonesian Journal On Networking And Security Vol. 5 No. 4 Oktober 2016.

[22] José O. Payero1, dkk., "Development of a Low-Cost Internet-ofThings (IoT) System for Monitoring Soil Water Potential Using Watermark 200SS Sensors". Advances in Internet of Things, 2017, 7, 7186 ISSN Online: 2161-6825 ISSN Print: 2161-6817 http://www.scirp.org/journal/ait

[23] IEEE, Issue 1 MAY 2015, "Towards Definition Internet of Things (IoT)", iot.ieee.org.

[24] Weiser, M.: The Computer for the 21st Century. Scientific American 265(9):66-75 (1991)

[25] Mattern, F., Floerkemeier, C.: From the Internet of Computers to the Internet of Things

[26] Bruhlman, Thomas. 2015. Arduino Praxiseinstieg. Jakarta :MITP.

[27] CodePolitan_Magazine_\#19-Internet_of_Things, Maret 2016

[28] Tanenbaum, AS, Computer Networks, Prentise Hall, 1996

[29] Stallings, W. Data and Computer Communications, Macmillan Publishing Company, 1985

[30] Black, U.D, Data Communications and Distributed Networks, Prentise Hall.

[31] https://cayenne.mydevices.com/ 
Wireless Smart Home System Menggunakan Internet Of Things 